\title{
Correction to: Deriving an overall appearance domain score by applying bifactor IRT analysis to the BODY-Q appearance scales
}

\author{
Daan Geerards ${ }^{1,2,3} \cdot$ Lisa van den Berg ${ }^{1,2,3} \cdot$ Andrea L. Pusic ${ }^{1,2} \cdot$ Maarten M. Hoogbergen $^{3} \cdot$ Anne F. Klassen $^{4}$. \\ René R. W. J. van der Hulst ${ }^{5}$. Chris J. Sidey-Gibbons ${ }^{1,2,6}$
}

Published online: 20 March 2021

(c) The Author(s) 2021

\section{Correction to: \\ Quality of Life Research (2020) 29:1065-1072 \\ https://doi.org/10.1007/s11136-019-02366-8}

In the original publication Table 1 has been removed as the authors did not obtain permission to reproduce the BODY-Q scale. A revised Table 1 is provided in this correction.

The original article has been corrected.

The original article can be found online at https://doi.org/10.1007/ s11136-019-02366-8.

Chris J. Sidey-Gibbons

cgibbons@mdanderson.org

1 Patient-Reported Outcomes, Value \& Experience (PROVE)

Center, Department of Surgery, Brigham and Women's

Hospital, 75 Francis St, Boston, MA 02115, USA

2 Department of Surgery, Harvard Medical School, Boston, MA, USA

3 Department of Plastic and Reconstructive Surgery, Catharina Ziekenhuis, Eindhoven, The Netherlands

4 Department of Pediatrics, McMaster University, Hamilton, ON, Canada

5 Department of Plastic and Reconstructive Surgery, Maastricht University Medical Center, Maastricht, The Netherlands

6 Department of Symptom Research, University of Texas MD Anderson Cancer Center, Houston, TX, USA 
Table 1 Satisfaction with body scale

\begin{tabular}{|c|c|c|c|c|}
\hline Item content $\mathrm{t}^{\mathrm{a}}$ & $\begin{array}{l}\text { Very } \\
\text { dissatis- } \\
\text { fied }\end{array}$ & $\begin{array}{l}\text { Somewhat } \\
\text { dissatisfied }\end{array}$ & $\begin{array}{l}\text { Some- } \\
\text { what } \\
\text { satisfied }\end{array}$ & $\begin{array}{l}\text { Very } \\
\text { satis- } \\
\text { fied }\end{array}$ \\
\hline 1.. looks when dressed & 1 & 2 & 3 & 4 \\
\hline 2.. how clothes fit & 1 & 2 & 3 & 4 \\
\hline 3.. size & 1 & 2 & 3 & 4 \\
\hline 4.. Shape & 1 & 2 & 3 & 4 \\
\hline 5.. looks in photos & 1 & 2 & 3 & 4 \\
\hline 6.. looks from behind & 1 & 2 & 3 & 4 \\
\hline 7.. Looks from the side & 1 & 2 & 3 & 4 \\
\hline $\begin{array}{l}\text { 8.. Looks in summer } \\
\text { clothes }\end{array}$ & 1 & 2 & 3 & 4 \\
\hline 7.. Looks from the side & 1 & 2 & 3 & 4 \\
\hline 9.. Looks in a swimsuit & 1 & 2 & 3 & 4 \\
\hline $\begin{array}{l}\text { 10.. Look in a mirror } \\
\text { unclothed }\end{array}$ & 1 & 2 & 3 & 4 \\
\hline
\end{tabular}

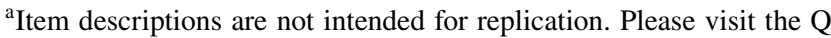
Portfolio website for full item wording
Open Access This article is licensed under a Creative Commons Attribution 4.0 International License, which permits use, sharing, adaptation, distribution and reproduction in any medium or format, as long as you give appropriate credit to the original author(s) and the source, provide a link to the Creative Commons licence, and indicate if changes were made. The images or other third party material in this article are included in the article's Creative Commons licence, unless indicated otherwise in a credit line to the material. If material is not included in the article's Creative Commons licence and your intended use is not permitted by statutory regulation or exceeds the permitted use, you will need to obtain permission directly from the copyright holder. To view a copy of this licence, visit http://creativecommons.org/licenses/by/4.0/.

Publisher's Note Springer Nature remains neutral with regard to jurisdictional claims in published maps and institutional affiliations. 